\title{
The Natural History of Food Sensitization in Children With Atopic Dermatitis and the Prognostic Role of Specific Serum IgE
}

\author{
Arianna Giannetti ${ }^{1}$, Giampaolo Ricci ${ }^{*}{ }^{1}$, Arianna Dondi ${ }^{1,2}$, Valentina Piccinno ${ }^{1}$, Federica Bellini ${ }^{1}$, \\ Roberto Rondelli ${ }^{1}$, Annalisa Patrizi ${ }^{2}$ and Andrea Pession ${ }^{1}$ \\ ${ }^{I}$ Pediatric Unit, Department of Gynecologic, Obstetric and Pediatric Sciences University of Bologna, Bologna, Italy \\ ${ }^{2}$ Dermatology Unit, Department of Specialist, Diagnostic and Experimental Medicine, University of Bologna, Bologna, \\ Italy
}

\begin{abstract}
Background: The natural history and the prognostic factors for food tolerance in childhood atopic dermatitis (AD) are poorly understood.

Objective: We aimed at investigating the natural course of egg and milk allergy in children affected by AD and food allergy and identifying if the persistence of allergy is associated with high specific serum $\operatorname{IgE}(\operatorname{sgE})$.

Methods: The retrospective study included 58 patients affected by AD, aged 9-16 months, with a first clinical examination between 1993 and 2002.

Results: Patients with AD and allergy to hen's egg $(\mathrm{N}=58)$ or cow's milk $(\mathrm{N}=44)$ were studied. In most patients milk and egg tolerance was reached before school age, but it was achieved later in children with severe AD and high egg sIgE.

Conclusions: The food tolerance is normally reached before school age and, at the time of diagnosis, levels of sIgE $>5 \mathrm{kU} / \mathrm{L}$ for hen's egg are risk factors for a later tolerance achievement.
\end{abstract}

Keywords: Atopic dermatitis, egg allergy, food allergy, milk allergy and specific serum IgE.

\section{INTRODUCTION}

Atopic dermatitis (AD) is a chronic inflammatory skin disease with specific immune and inflammatory mechanisms that affects between $15 \%$ to $30 \%$ of the pediatric population with an age dependency [1,2]. Food allergy is much more common in children with $\mathrm{AD}$, with an association of $15-30 \%$ (even if some authors report it to be up to 80\%) [3-6].

The main offending foods are cow's milk, hen's egg, peanuts and fish [7].

Sensitization to food occurs early, peaking at approximately 6 to 9 months of age [8] and generally does not increase later in childhood $[9,10]$.

Three prospective studies showed that about two-thirds of children will outgrow their egg allergy by early school age [11-13]. However, a recent large, retrospective review by Savage et al. [14] of 881 egg-allergic individuals reported that a significant proportion of egg allergic patients was still allergic in their late childhood or adolescence.

The overall prognosis of cow's milk allergy is also good, with a total recovery of $56 \%$ at 1 year, $77 \%$ at 2 years, $87 \%$ at 3 years, $92 \%$ at 5 and 10 years and $97 \%$ at 15 years of age [15].

*Address correspondence to this author at the Pediatric Unit, Department of Gynecologic, Obstetric and Pediatric Sciences, University of Bologna, via Massarenti $\mathrm{n}^{\circ}$ 11, 40138, Bologna, Italy; Tel: +39 051 6363075; Fax: +39 051 6364829; E-mail: giampaolo.ricci@unibo.it
In a previous study which included children with a diagnosis of $\mathrm{AD}$ and first examined at an age of 9 to 16 months, our group showed that the presence of allergic sensitization at one year of age might predict the development of respiratory allergy [16].

The aim of the present study is to investigate the natural course of and acquisition of tolerance in hen's egg and cow's milk allergy in children with AD and to identify if allergy persistence is associated with high $\operatorname{SIgE}$.

\section{MATERIALS AND METHODS}

\section{Study Population and Inclusion Criteria}

Patients included in this study represent a part of the cohort already analyzed in a previous retrospective study [16], in which children were enrolled according to the following criteria:

a. diagnosis of $\mathrm{AD}$ at an age of 9 to 16 months made at our Pediatric Allergology Outpatients Clinic, with a first clinical examination between 1993 and 2002;

b. availability of a detailed family and personal history;

c. performance of allergometric tests (skin prick tests (SPTs) and sIgE serum level for food and inhalant allergens);

d. telephone availability;

e. informed consent by the parents. 


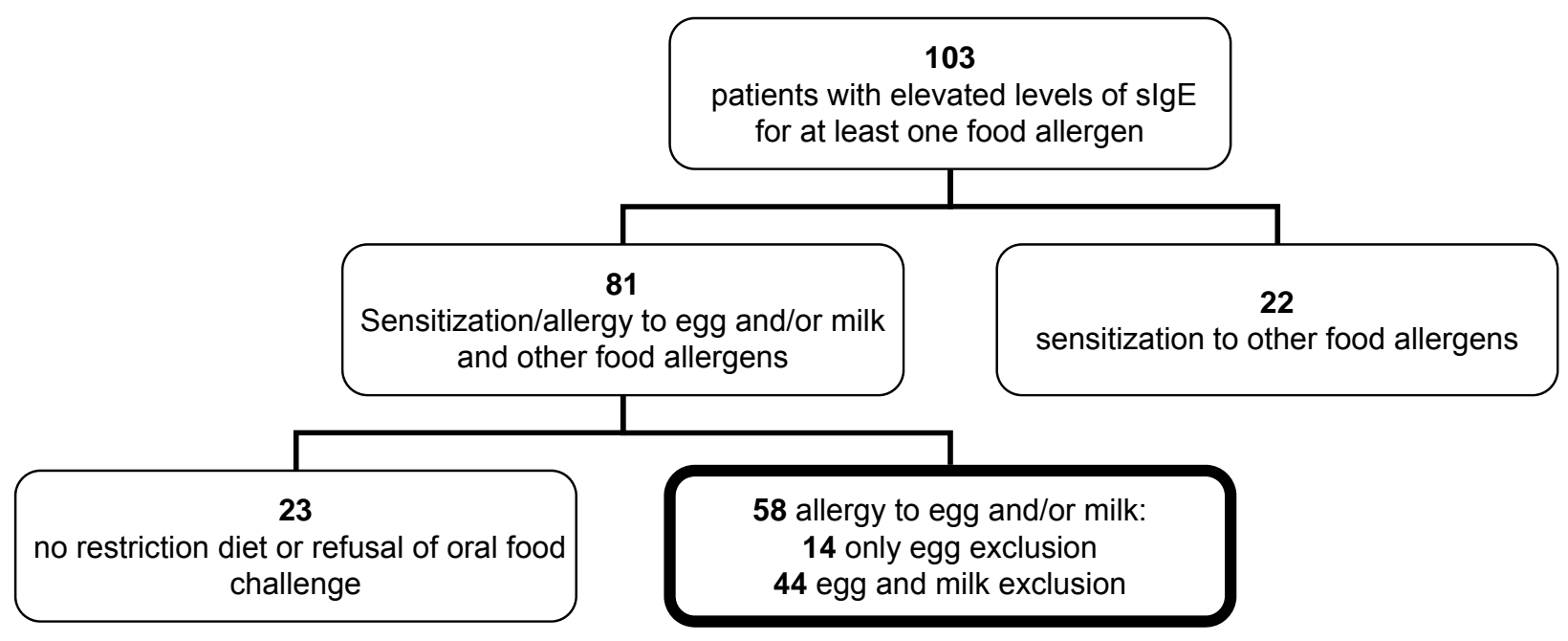

Fig. (1). Study population flow chart.

For the present analysis, we selected those patients with sIgE $>0.35 \mathrm{kU} / \mathrm{L}$ for at least one food allergen at first observation $(\mathrm{n}=103)$, only $81(78.6 \%)$ of whom with a sensitization and/or food allergy to cow's milk and hen's egg. Among them, 23 children were not on a restriction diet or refused to perform food challenge, whereas 58 were on hen's egg or cow's milk exclusion diet (Fig. 1). Therefore, we performed our analysis on 58 children: 14 were allergic to hen's egg (with symptoms of urticaria in 11 patients and $\mathrm{AD}$ acute flares in 3) and on an egg-free diet; the others were allergic to milk and sensitized to egg, so that they followed a milk and egg restriction diet on the basis of milk-allergy symptoms, AD severity and elevated hen's egg sIgE. In the 44 children with cow's milk allergy the symptoms were: acute flares of $\mathrm{AD}$ (7 patients), urticaria (34 patients), respiratory (1 patient), gastrointestinal (2 patients) (Table $\mathbf{1})$.

The patients were followed with periodic check-ups until $\mathrm{AD}$ was controlled and they had reached the tolerance for the food. Oral challenges were repeated every 6-9 months (mean: 8 months) for 24 months after a diagnostic challenge and on a yearly basis thereafter. Accidental ingestion of a considerable amount of the offending food without a clinical reaction was considered as a negative challenge: this happened in 5 children for cow's milk and in 6 children for hen's egg (Table 1). If a reported accidental ingestion had produced clinical symptoms, the reported dose ingested was recorded. In this case, convincing symptoms were considered as positive oral food challenges and the scheduled follow-up was delayed of 6-12 months.

Milk/egg hypersensitivity was assumed to have resolved when a whole egg or an entire glass of milk $(150 \mathrm{ml})$ could be eaten or drunk with no apparent symptoms.

\section{Clinical Assessment}

At the time of the first evaluation, the diagnosis of $\mathrm{AD}$ was made by the physicians on the basis of the criteria of Hanifin and Rajka [17] and the evaluation of the severity of AD was assessed by the SCORAD index [18]. SCORAD index $<25$ shows a mild $\mathrm{AD}$ (8 patients, $14 \%), 25-50$ a moderate form (39 patients, $67 \%$ ), $>50$ a severe form (11 patients, $19 \%$ ).

\section{Allergometric Assessment}

At the first evaluation (between 1993 and 2002) the determination of SIgE was performed by ImmunoCAPTM (Pharmacia, Sweden) in all patients for the following allergens: cow's milk, hen's egg, soybean, wheat, peanut, nut, codfish, apple. A patient was considered as sensitized to an allergen when having sIgE levels higher than $0.35 \mathrm{kU} / \mathrm{L}$.

All the sera were tested for sIgE levels in the central laboratory of our hospital.

\section{Statistical Methods}

Standard statistical descriptions of parameters were used to characterize the data (mean, median and range).

The primary outcomes were tolerance onset to cow's milk and to hen's egg in children with AD and duration of intolerance to both food allergens.

Both outcomes were estimated using the method of Kaplan and Meier; comparison between probabilities in different patient groups was performed using the log-rank test [19].

Tolerance onset probabilities to cow's milk and to hen's egg were computed from the date of diagnosis to the date of tolerance onset to cow's milk and to hen's egg respectively, while duration of intolerance (or persistence of allergy) was calculated from the onset to the disappearing of the allergy or the last date of contact.

Results were expressed as probability (\%). All $\mathrm{P}$ values are 2 -sided and values less than 0.05 were considered as statistically significant.

The Statistical analysis was performed using the STATA package [20].

\section{RESULTS}

All the 58 patients ( 35 males, 23 females) were on an egg-free diet; $44(76 \%)$ were also on a milk-free diet. The mean follow-up of these patients was $127.6 \pm 24.7$ months. The mean age of children at first observation was 11.2 months. At follow-up the mean age was 138.8 months. 
Table 1. Characteristics of the Population

\begin{tabular}{|c|c|c|c|c|c|c|c|c|c|}
\hline $\begin{array}{l}\text { Patient } \\
\text { Number }\end{array}$ & $\begin{array}{c}\text { Food } \\
\text { Allergy }\end{array}$ & $\begin{array}{l}\text { Symtoms of } \\
\text { Egg Allergy }\end{array}$ & $\begin{array}{l}\text { Symtoms of } \\
\text { Milk Allergy }\end{array}$ & $\begin{array}{c}\operatorname{sIgE~Egg} \\
(\mathrm{kU} / \mathrm{L})\end{array}$ & $\begin{array}{c}\text { sIgE Milk } \\
\text { (kU/L) }\end{array}$ & $\begin{array}{l}\text { OFC } \\
\text { Egg }\end{array}$ & $\begin{array}{l}\text { OFC } \\
\text { Milk }\end{array}$ & $\begin{array}{l}\text { OCF Egg } \\
\text { Outcome }\end{array}$ & $\begin{array}{c}\text { OCF Milk } \\
\text { Outcome }\end{array}$ \\
\hline 1 & Egg & $\mathrm{U}$ & & 100 & & Yes & Yes & $\mathrm{T}$ & $\mathrm{T}$ \\
\hline 2 & Egg & $\mathrm{U}$ & & 64.1 & & Yes & Yes & $\mathrm{T}$ & $\mathrm{T}$ \\
\hline 3 & Egg & $\mathrm{U}$ & & 44 & & Yes & Yes & $\mathrm{T}$ & $\mathrm{T}$ \\
\hline 4 & Egg & $\mathrm{U}$ & & 25.4 & & Yes & Yes & $\mathrm{T}$ & $\mathrm{T}$ \\
\hline 5 & Egg & $\mathrm{U}$ & & 30 & & Yes & Yes & $\mathrm{T}$ & $\mathrm{T}$ \\
\hline 6 & Egg & $\mathrm{U}$ & & 26.8 & & Yes & Yes & $\mathrm{T}$ & $\mathrm{T}$ \\
\hline 7 & Egg & $\mathrm{U}$ & & 21.8 & & Yes & Yes & $\mathrm{T}$ & $\mathrm{T}$ \\
\hline 8 & Egg & $\mathrm{U}$ & & 39.3 & & Yes & Yes & $\mathrm{T}$ & $\mathrm{T}$ \\
\hline 9 & Egg & $\mathrm{U}$ & & 21 & & Yes & Yes & $\mathrm{T}$ & $\mathrm{T}$ \\
\hline 10 & Egg & $\mathrm{U}$ & & 15.9 & & Yes & Yes & $\mathrm{T}$ & $\mathrm{T}$ \\
\hline 11 & Egg & $\mathrm{U}$ & & 19 & & Yes & Yes & $\mathrm{T}$ & $\mathrm{T}$ \\
\hline 12 & Egg & ADaf & & 17 & & Yes & Yes & $\mathrm{T}$ & $\mathrm{T}$ \\
\hline 13 & Egg & ADaf & & 15.1 & & Yes & Yes & $\mathrm{T}$ & $\mathrm{T}$ \\
\hline 14 & Egg & ADaf & & 17.6 & & Yes & Yes & $\mathrm{T}$ & $\mathrm{T}$ \\
\hline 15 & Egg+milk & $\mathrm{N}$ & $\mathrm{U}$ & 15.3 & 23.6 & A & Yes & $\mathrm{T}$ & $\mathrm{T}$ \\
\hline 16 & Egg+milk & $\mathrm{N}$ & $\mathrm{U}$ & 7.7 & 1 & A & Yes & $\mathrm{T}$ & $\mathrm{T}$ \\
\hline 17 & Egg+milk & $\mathrm{N}$ & $\mathrm{U}$ & 6.6 & 7.3 & $\mathrm{~A}$ & Yes & $\mathrm{T}$ & $\mathrm{T}$ \\
\hline 18 & Egg+milk & $\mathrm{N}$ & $\mathrm{U}$ & 4.9 & 5.1 & A & Yes & $\mathrm{T}$ & $\mathrm{T}$ \\
\hline 19 & Egg+milk & $\mathrm{N}$ & $\mathrm{U}$ & 3.7 & 5.7 & $\mathrm{~A}$ & Yes & $\mathrm{T}$ & $\mathrm{T}$ \\
\hline 20 & Egg+milk & $\mathrm{N}$ & $\mathrm{U}$ & 2.1 & 7.5 & A & Yes & $\mathrm{T}$ & $\mathrm{T}$ \\
\hline 21 & Egg+milk & $\mathrm{N}$ & $\mathrm{U}$ & 13 & 4 & Yes & A & $\mathrm{T}$ & $\mathrm{T}$ \\
\hline 22 & Egg+milk & $\mathrm{N}$ & $\mathrm{U}$ & 3.4 & 17.3 & Yes & $\mathrm{A}$ & $\mathrm{T}$ & $\mathrm{T}$ \\
\hline 23 & Egg+milk & $\mathrm{N}$ & $\mathrm{U}$ & 1.9 & 2.7 & Yes & A & $\mathrm{T}$ & $\mathrm{T}$ \\
\hline 24 & Egg+milk & $\mathrm{N}$ & $\mathrm{U}$ & 4.9 & 3 & Yes & A & $\mathrm{T}$ & $\mathrm{T}$ \\
\hline 25 & Egg+milk & $\mathrm{N}$ & $\mathrm{U}$ & 10 & 2.2 & Yes & $\mathrm{A}$ & $\mathrm{T}$ & $\mathrm{T}$ \\
\hline 26 & Egg+milk & $\mathrm{N}$ & $\mathrm{U}$ & 5.4 & 16 & Yes & Yes & $\mathrm{T}$ & $\mathrm{T}$ \\
\hline 27 & Egg+milk & $\mathrm{N}$ & $\mathrm{U}$ & 1.7 & 2.7 & Yes & Yes & $\mathrm{T}$ & $\mathrm{T}$ \\
\hline 28 & Egg+milk & $\mathrm{N}$ & $\mathrm{U}$ & 7.5 & 4.5 & Yes & Yes & $\mathrm{T}$ & $\mathrm{T}$ \\
\hline 29 & Egg+milk & $\mathrm{N}$ & $\mathrm{U}$ & 5.5 & 3.6 & Yes & Yes & $\mathrm{T}$ & $\mathrm{T}$ \\
\hline 30 & Egg+milk & $\mathrm{N}$ & $\mathrm{U}$ & 4.9 & 8 & Yes & Yes & $\mathrm{T}$ & $\mathrm{T}$ \\
\hline 31 & Egg+milk & $\mathrm{N}$ & $\mathrm{U}$ & 3.5 & 5.1 & Yes & Yes & $\mathrm{T}$ & $\mathrm{T}$ \\
\hline 32 & Egg+milk & $\mathrm{N}$ & $\mathrm{U}$ & 10 & 3.2 & Yes & Yes & $\mathrm{T}$ & $\mathrm{T}$ \\
\hline 33 & Egg+milk & $\mathrm{N}$ & $\mathrm{U}$ & 7.7 & 44.8 & Yes & Yes & $\mathrm{T}$ & $\mathrm{T}$ \\
\hline 34 & Egg+milk & $\mathrm{N}$ & $\mathrm{U}$ & 4.8 & 3.4 & Yes & Yes & $\mathrm{T}$ & $\mathrm{T}$ \\
\hline 35 & Egg+milk & $\mathrm{N}$ & $\mathrm{U}$ & 2.4 & 7.1 & Yes & Yes & $\mathrm{T}$ & $\mathrm{T}$ \\
\hline 36 & Egg+milk & $\mathrm{N}$ & $\mathrm{U}$ & 6.3 & 5.5 & Yes & Yes & $\mathrm{T}$ & $\mathrm{T}$ \\
\hline 37 & Egg+milk & $\mathrm{N}$ & $\mathrm{U}$ & 2.2 & 2.1 & Yes & Yes & $\mathrm{T}$ & $\mathrm{T}$ \\
\hline 38 & Egg+milk & $\mathrm{N}$ & $\mathrm{U}$ & 12 & 2 & Yes & Yes & $\mathrm{T}$ & $\mathrm{T}$ \\
\hline 39 & Egg+milk & $\mathrm{N}$ & $\mathrm{U}$ & 4.1 & 44 & Yes & Yes & $\mathrm{T}$ & $\mathrm{T}$ \\
\hline 40 & Egg+milk & $\mathrm{N}$ & $\mathrm{U}$ & 1.6 & 1.2 & Yes & Yes & $\mathrm{T}$ & $\mathrm{T}$ \\
\hline 41 & Egg+milk & $\mathrm{N}$ & $\mathrm{U}$ & 2.8 & 0.9 & Yes & Yes & $\mathrm{T}$ & $\mathrm{T}$ \\
\hline
\end{tabular}


(Table 1) contd.....

\begin{tabular}{|c|c|c|c|c|c|c|c|c|c|}
\hline $\begin{array}{c}\text { Patient } \\
\text { Number }\end{array}$ & $\begin{array}{c}\text { Food } \\
\text { Allergy }\end{array}$ & $\begin{array}{l}\text { Symtoms of } \\
\text { Egg Allergy }\end{array}$ & $\begin{array}{l}\text { Symtoms of } \\
\text { Milk Allergy }\end{array}$ & $\begin{array}{c}\text { sIgE Egg } \\
(\mathrm{kU} / \mathrm{L})\end{array}$ & $\begin{array}{l}\text { sIgE Milk } \\
\text { (kU/L) }\end{array}$ & $\begin{array}{l}\text { OFC } \\
\text { Egg }\end{array}$ & $\begin{array}{l}\text { OFC } \\
\text { Milk }\end{array}$ & $\begin{array}{l}\text { OCF Egg } \\
\text { Outcome }\end{array}$ & $\begin{array}{l}\text { OCF Milk } \\
\text { Outcome }\end{array}$ \\
\hline 42 & Egg+milk & $\mathrm{N}$ & $\mathrm{U}$ & 1.3 & 57.8 & Yes & Yes & $\mathrm{T}$ & $\mathrm{T}$ \\
\hline 43 & Egg+milk & $\mathrm{N}$ & $\mathrm{U}$ & 11.6 & 9.8 & Yes & Yes & $\mathrm{T}$ & $\mathrm{T}$ \\
\hline 44 & Egg+milk & $\mathrm{N}$ & $\mathrm{U}$ & 1.3 & 1.2 & Yes & Yes & $\mathrm{T}$ & $\mathrm{T}$ \\
\hline 45 & Egg+milk & $\mathrm{N}$ & $\mathrm{U}$ & 1.1 & 10 & Yes & Yes & $\mathrm{T}$ & $\mathrm{T}$ \\
\hline 46 & Egg+milk & $\mathrm{N}$ & $\mathrm{U}$ & 10.6 & 0.9 & Yes & Yes & $\mathrm{T}$ & $\mathrm{T}$ \\
\hline 47 & Egg+milk & $\mathrm{N}$ & $\mathrm{U}$ & 0.6 & 12 & Yes & Yes & $\mathrm{T}$ & NT \\
\hline 48 & Egg+milk & $\mathrm{N}$ & $\mathrm{U}$ & 12.3 & 1.6 & Yes & Yes & NT & $\mathrm{T}$ \\
\hline 49 & Egg+milk & $\mathrm{N}$ & $\mathrm{R}$ & 13.7 & 88.3 & Yes & Yes & NT & NT \\
\hline 50 & Egg+milk & $\mathrm{N}$ & G & 5.1 & 0.4 & Yes & Yes & $\mathrm{T}$ & $\mathrm{T}$ \\
\hline 51 & Egg+milk & $\mathrm{N}$ & G & 1.3 & 0.5 & Yes & Yes & $\mathrm{T}$ & $\mathrm{T}$ \\
\hline 52 & Egg+milk & $\mathrm{N}$ & ADaf & 0.6 & 0.7 & Yes & Yes & $\mathrm{T}$ & $\mathrm{T}$ \\
\hline 53 & Egg+milk & $\mathrm{N}$ & ADaf & 0.4 & 1.5 & Yes & Yes & $\mathrm{T}$ & $\mathrm{T}$ \\
\hline 54 & Egg+milk & $\mathrm{N}$ & ADaf & 0.5 & 0.4 & Yes & Yes & $\mathrm{T}$ & $\mathrm{T}$ \\
\hline 55 & Egg+milk & $\mathrm{N}$ & $\mathrm{ADaf}$ & 0.5 & 0.4 & Yes & Yes & $\mathrm{T}$ & $\mathrm{T}$ \\
\hline 56 & Egg+milk & $\mathrm{N}$ & ADaf & 0.4 & 0.4 & Yes & Yes & $\mathrm{T}$ & $\mathrm{T}$ \\
\hline 57 & Egg+milk & $\mathrm{N}$ & ADaf & 0.5 & 1.5 & Yes & Yes & $\mathrm{T}$ & $\mathrm{T}$ \\
\hline 58 & Egg+milk & $\mathrm{N}$ & ADaf & 0.5 & 0.5 & Yes & Yes & $\mathrm{T}$ & $\mathrm{T}$ \\
\hline
\end{tabular}

OCF: Oral food challenge; A: accidental ingestion of the offending food; U: urticaria; R: respiratory, G: gastrointestinal; ADaf: AD acute flares; N: none; T: tolerance, NT: No Tolerance/

Out of all the patients, 56 children $(97 \%)$ developed tolerance to egg at a mean age of 46 months (range 13-156) and $42(96 \%)$ to milk at a mean age of 37 months (range 10115) (Fig. 2A, B).

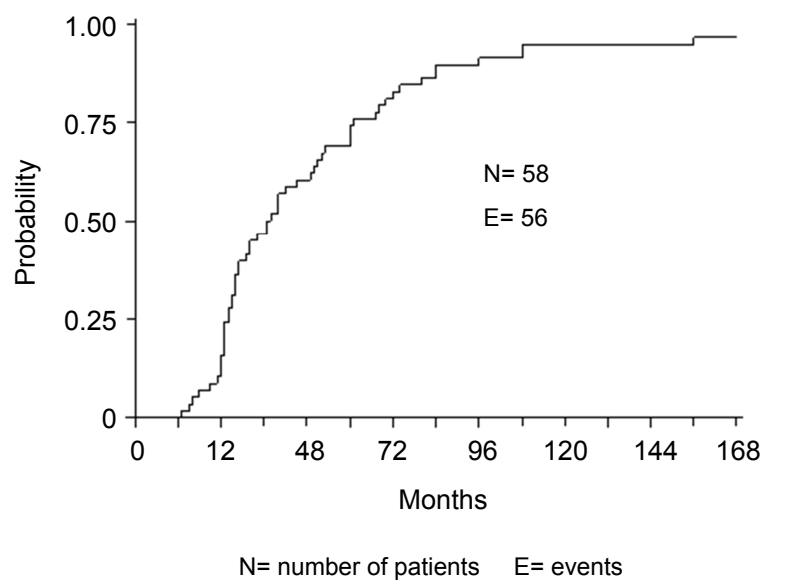

Fig. (2A). Tolerance onset to hen's egg in children with AD.

Furthermore, the patients with mild $\mathrm{AD}$ achieved the tolerance to milk and egg at a mean age respectively of 29 and 44 months, earlier than those with severe $A D$, who reached the tolerance respectively at a mean age of 53 and 57 months, although these differences were not statistically significant (Fig. 3A, B).

Figs. (4A, B) show the Kaplan Meier curves for duration of the disease stratified according to the levels of sIgE.

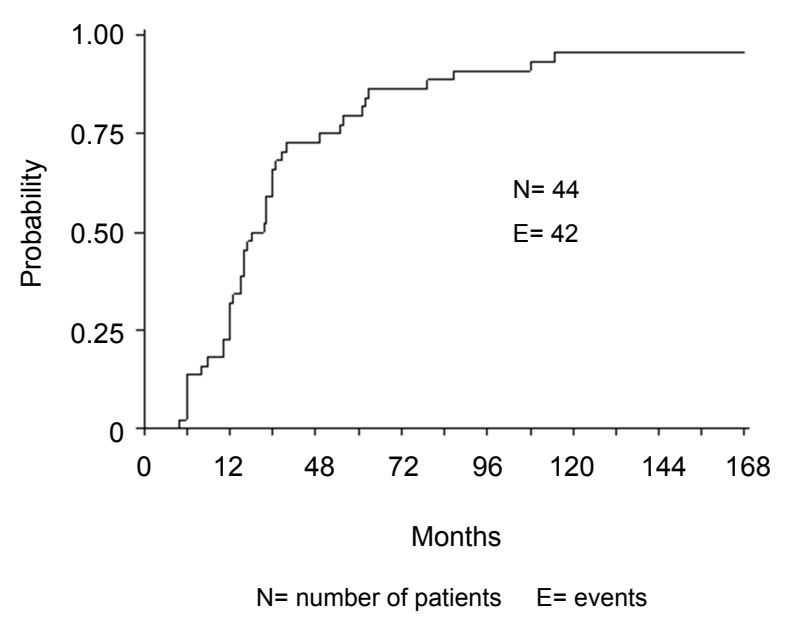

Fig. (2B). Tolerance onset to cow's milk in children with AD.

The patients were divided into two groups according to the median of sIgE (egg white: $5 \mathrm{kU} / \mathrm{L}$, milk: $3 \mathrm{kU} / \mathrm{L}$ ). Children with $\operatorname{sgE}$ levels $\leq 5 \mathrm{kU} / \mathrm{L}$ for hen's egg white reached the tolerance significantly earlier than those with levels higher than $5 \mathrm{kU} / \mathrm{L}(P=0.002)$. Patients with cow's milk sIgE levels $\leq 3 \mathrm{kU} / \mathrm{L}$ apparently became tolerant earlier than those with $\operatorname{sIgE~}>3 \mathrm{kU} / \mathrm{L}$, but this difference was not statistically significant (Fig. 4A, B).

\section{DISCUSSION}

The natural course of food allergy is different for each allergen. Allergies to peanuts, nuts, and seafood are more likely to persist, with a small fraction of patients developing 
tolerance, whereas allergies to milk, eggs, wheat, and soy generally resolve by childhood [21].

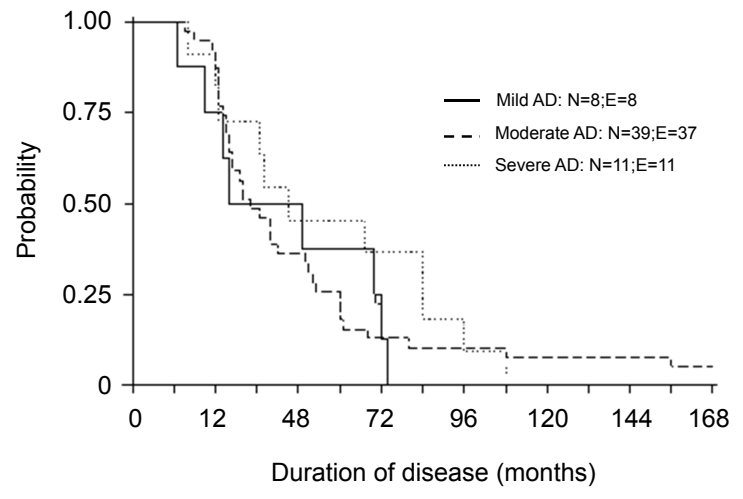

$\mathrm{N}=$ number of patients, $\mathrm{E}=$ events; Overall Log-rank $\mathrm{p}=0.68$

Fig. (3A). Curve for duration of hen's egg white intolerance stratified according to the severity of AD.

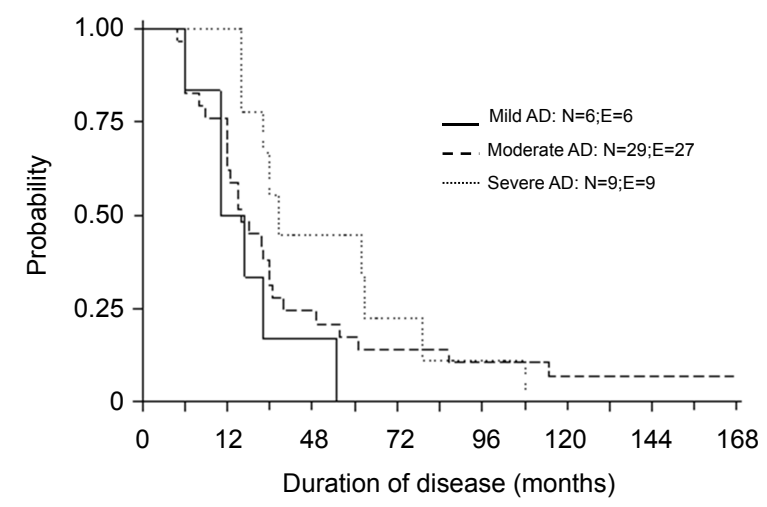

$\mathrm{N}=$ number of patients, $\mathrm{E}=$ events; Overall Log-rank $p=0.23$

Fig. (3B). Curve for duration of cow's milk intolerance stratified according to the severity of AD.

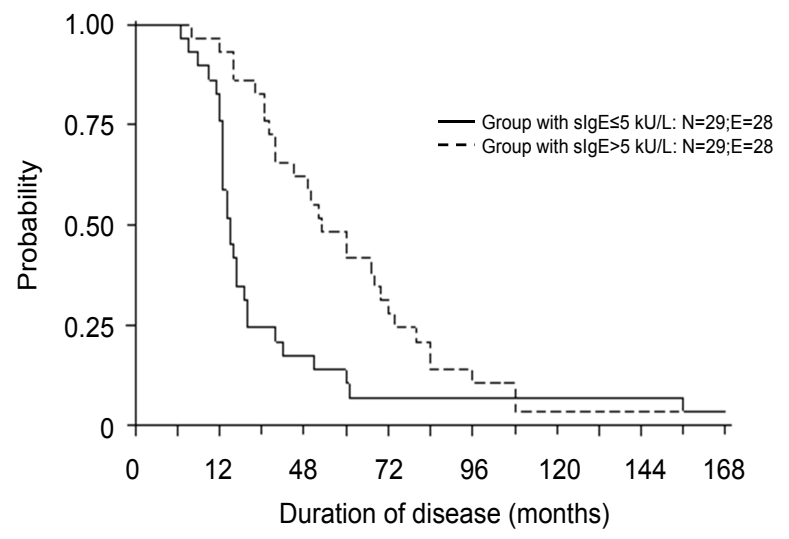

$N=$ number of patients, $E=$ events; Log-rank $p=0.0023$

Fig. (4A). Curve for duration of the disease stratified according to the hen's egg white IgE levels. The patients were divided into two groups according to the median of $\operatorname{sIgE}(5 \mathrm{kU} / \mathrm{L})$.

In the paper, we found that the tolerance for egg and milk was reached early: at 46 months to egg and at 37 months of age to milk (Fig. 2A, B). Several studies report that most children with egg allergy outgrow their allergy by the early school-age years, whereas children affected by cow's milk allergy will probably tolerate the food by the age of $3[15,10$, 22-24].

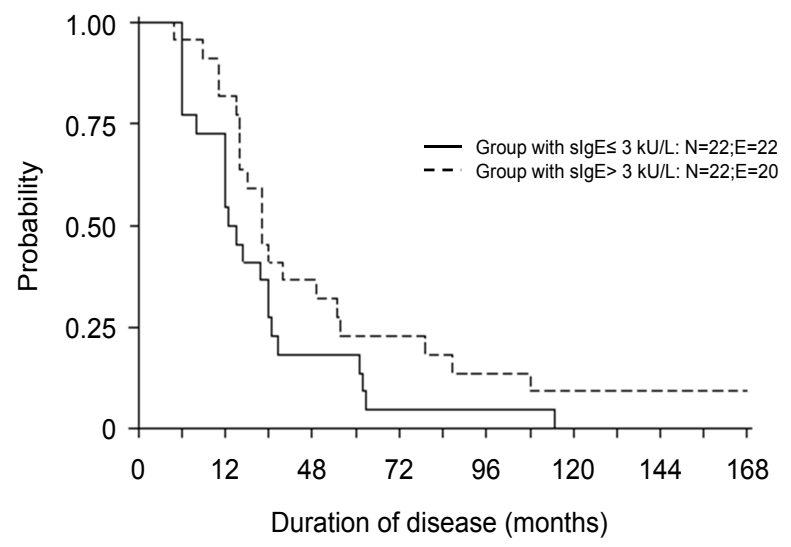

$\mathrm{N}=$ number of patients, $\mathrm{E}=$ events; Log-rank $\mathrm{p}=0.095$

Fig. (4B). Curve for duration of the disease stratified according to the cow's milk IgE levels. The patients were divided into two groups according to the median of $\operatorname{sIgE}(3 \mathrm{kU} / \mathrm{L})$.

Other studies report that between $31 \%$ and $51 \%$ of children allergic to egg usually overcome the problem [11,25-27]. According to Boyano-Martinez et al. [13], who studied 58 patients younger than 2 years of age with egg allergy, half of the children will tolerate the food at 35 months of follow-up and $66 \%$ after 5 years. In a prospective, birth cohort study on 1749 Danish children who were followed up to the age of 3, Høst and Halken [15] found that the prevalence of milk allergy was $2.2 \%$ and that, by the age of 3 , most of the allergic children were able to tolerate milk.

However, other studies suggest a modification of the natural history of cow's milk and hen's egg allergy, with increasing persistence until a later age $[14,28]$. In the large, retrospective review of 881 egg allergic individuals by Savage et al. [14], the rate of tolerance development, depending on the definition of egg allergy, was 36-66\% by 10 years, $61-86 \%$ by 14 years and $80-95 \%$ by age 16 years. Skripak et al. [28] retrospectively analyzed 807 patients with IgE-mediated milk allergy and, despite the use of 3 sets of increasingly broad criteria to define tolerance, incidence rates of resolution at 4 years ranged from $<1 \%$ to $26 \%$, substantially lower than previously reported.

Unfortunately, it is difficult to compare results between studies because of different ages at study entry, different follow-up times and unlike populations; it is also possible that ethnic and genetic variations play a role in the development of oral tolerance. The main limitation of our study is that 44 patients were diagnosed with egg allergy on the basis of sIgE alone and did not have a history of reaction to food. This occurred because these children were being evaluated for AD before egg had been introduced into their diet, and then strict egg avoidance was instituted on the basis of a milk-free diet, the elevated $\operatorname{sigE}$ and/or the severity of AD. An oral provocation test had not been proposed to the parents until the levels of sIgE were below the threshold of 7 $\mathrm{kU} / \mathrm{L}$, which predicts a high risk of reaction to food ingestion. 
Although the natural history of egg and milk allergy has been thoroughly evaluated, previous results have been somewhat contradictory and an exact determination of when tolerance is acquired in each individual case is still not possible. Moreover, the prognostic factors for the development of tolerance in food allergy are poorly understood. Another aim of our study was to analyze the relationship between tolerance acquirement and the values of SIgE and AD severity as assessed at the time of the first examination. The predictive factors identified may help to define the prognosis of food allergy in each particular case and to answer parents' common questions about when their child will tolerate the ingestion of the offending food and when he or she will be able to reintroduce food in his or her diet.

Similarly to what has been reported by others [13, 29, 30], we found a very important role of high sIgE in predicting the persistence of allergy and, in particular, that patients with levels of sIgE for hen's egg white higher than 5 $\mathrm{kU} / \mathrm{L}$ at diagnosis reach the tolerance later than those with lower levels (Fig. 4A).

In a study which included children between 3 months and 14 years of age, $61 \%$ with $\mathrm{AD}$ and $90 \%$ with a family history of atopy [29], Sampson and Ho reported that in the presence of egg $\mathrm{sIgE} \geq 7 \mathrm{kU} / \mathrm{L}$, provocation testing would not be indicated, given the high probability that the test would prove positive. In the work by Boyano-Martínez et al. [13], the sIgE level is an important prognostic marker in children who only had cutaneous symptoms. Savage et al. [14], examining the relationship between the peak of egg $\operatorname{sgE}$ level and the development of tolerance, have identified an egg $\operatorname{sgE}$ level $\geq 50 \mathrm{kU} / \mathrm{L}$ as a marker of persistent egg allergy.

Montesinos et al. [30] performed a retrospective study of patients with egg allergy and found that the initial levels of SIgE for egg white were significantly lower in those patients who reached tolerance: sIgE levels of $1.52,1.35$ and 2.59 $\mathrm{kU} / \mathrm{L}$ predicted clinical reactivity at the different follow-up timepoints analyzed (25-36, 37-48 and 49-60 months respectively).

Our study shows that high levels of sIgE for milk are not a risk factor for a later tolerance achievement.

However, in a recent study [31] on a population of 139 Portuguese children with milk allergy, higher sIgE levels to cow's milk (>17.5 kU/L) during the follow-up period were associated with a reduced likelihood of acquiring oral tolerance.

Also in the work of Vanto et al. [32] the milk sIgE levels $>2 \mathrm{kU} / \mathrm{L}$ are useful prognostic indicators of the development of tolerance to milk in infants with milk allergy.

Levy et al. [33] compared patient with transient milk allergy with those with persistent milk allergy: no differences were found between the groups in mean age and symptoms and signs at the first allergic reaction and family history of atopy.

Food-sensitized children have been shown to have more severe and persistent $\mathrm{AD}[5,34,35]$. The patients that develop $\mathrm{AD}$ before 3 months of age are at significantly greater risk of acquiring food allergies compared with those who develop
AD after 12 months of age [5,36]. These data suggest that the presence of food sensitization and allergy earlier in life predicts a prognosis of severe $\mathrm{AD}$, but conclusions about its role in the pathogenesis of AD cannot be drawn. In our study the patients with mild AD achieved the tolerance to milk and egg (with a mean respectively of 29 and 44 months) earlier than those with severe $\mathrm{AD}$ (with a mean respectively of 53 and 57 months) although not statistically significant (Fig. 3A, B).

In conclusion, our study seems to highlight that, in the case of milk and egg allergy, food tolerance is normally reached before school age and that initial sIgE levels $>5$ $\mathrm{kU} / \mathrm{L}$ for hen's egg white are risk factors for a later tolerance achievement.

\section{CONFLICT OF INTEREST}

The authors confirm that this article content has no conflict of interest.

\section{ACKNOWLEDGEMENTS}

Declared none.

\section{REFERENCES}

[1] Bieber T. Atopic dermatitis. N Engl J Med 2008; 358: 1483-94.

[2] Liu FT, Goodarzi H, Chen HY. IgE, Mast Cells, and Eosinophils in Atopic Dermatitis. Clin Rev Allergy Immunol 2011; 41: 298-310.

[3] Illi S, von Mutius E, Lau S, et al. The natural course of atopic dermatitis from birth to age 7 years and the association with asthma. J Allergy Clin Immunol 2004; 113: 925-31.

[4] Eigenmann PA, Sicherer SH, Borkowski TA, Cohen BA, Sampson HA. Prevalence of IgE-mediate food allergy among children with atopic dermatitis. Pediatrics 1998; 101: E8.

[5] Hill DJ, Hosking CS, De Benedictis FM, Oranje AP, Diepgen TL, Bauchau V; EPAAC Study Group. Confirmation of the association between high levels of immunoglobulin $\mathrm{E}$ food sensitization and eczema in infancy: An international study. Clin Exp Allergy 2008; 3: $161-8$.

[6] Eller E, Kjaer HF, Host A, Andersen KE, Bindslev-Jensen C. Food allergy and food sensitization in early childhood: results from the DARC cohort. Allergy 2009; 64: 1023-9.

[7] Suh KY. Food allergy and atopic dermatitis: separating fact from fiction. Semin Cutan Med Surg 2010; 29: 72-8.

[8] Bath-Hextall F, Delamere FM, Williams HC. Dietary exclusion for improving established atopic eczema in adults and children: systematic review. Allergy 2009; 64: 258-64

[9] Brockow I, Zutavern A, Hoffman U, et al. Early allergic sensitizations and their relevance to atopic diseases in children aged 6 years: results of the GINI study. J Investig Allergol Clin Immunol 2009; 19: 180-7.

[10] Bock SA. Prospective appraisal of complaints of adverse reactions to foods in children during the first 3 years of life. Pediatrics 1987; 79: 683-8.

[11] Ford RP, Taylor B. Natural history of egg hypersensitivity. Arch Dis Child 1982; 57: 649-52.

[12] Dannaeus A, Inganäs M. A follow-up study of children with food allergy. Clinical course in relation to serum IgE- and IgG-antibody levels to milk, egg and fish. Clin Allergy 1981; 11: 533-9.

[13] Boyano-Martínez T, García-Ara C, Díaz-Pena JM, Martín-Esteban M. Prediction of tolerance on the basis of quantification of egg white-specific IgE antibodies in children with egg allergy. J Allergy Clin Immunol 2002; 110: 304-9.

[14] Savage JH, Matsui EC, Skripak JM, Wood RA. The natural history of egg allergy. J Allergy Clin Immunol 2007; 120: 1413-7.

[15] Høst A, Halken S, Jacobsen HP, Christensen AE, Herskind AM, Plesner K. Clinical course of cow's milk protein allergy/intolerance and atopic diseases in childhood. Pediatr Allergy Immunol 2002; 13 Suppl 15: 23-8.

[16] Ricci G, Patrizi A, Giannetti A, Dondi A, Bendandi B, Masi M. Does improvement management of atopic dermatitis influence the 
appearance of respiratory allergic diseases? A follow-up study. Clin Mol Allergy 2010; 8: 8.

[17] Hanifin JM, Rajka G. Diagnostic features of atopic dermatitis. Acta Derm Venereol Suppl (Stockh) 1980; 92: 44-7.

[18] Consensus Report of the European Task Force on Atopic Dermatitis. Severiy scoring of atopic dermatitis: the SCORAD index. Dermatology 1993; 186: 23-31.

[19] Kaplan EL, Meier P. Nonparametral estimation from incomplete observations. J Am Stat Assoc 1958; 53: 457.

[20] StataCorp, STATA Statistical Software: Release 7.0. College Station, TX: Stata Corporation 2000.

[21] Lack G. Clinical practice. Food allergy. N Engl J Med 2008; 359: 1252-60.

[22] Saarinen KM, Juntunen-Backman K, Järvenpää AL, et al. Supplementary feeding in maternity hospitals and the risk of cow's milk allergy: A prospective study of 6209 infants. J Allergy Clin Immunol 1999; 104: 457-61.

[23] Schrander JJ, van den Bogart JP, Forget PP, Schrander-Stumpel $\mathrm{CT}$, Kuijten RH, Kester AD. Cow's milk protein intolerance in infants under 1 year of age: a prospective epidemiological study. Eur J Pediatr 1993; 152: 640-4.

[24] Bishop JM, Hill DJ, Hosking CS. Natural history of cow milk allergy: clinical outcome. J Pediatr 1990; 116: 862-7.

[25] Sampson HA, Scanlon SM. Natural history of food hypersensitivity in children with atopic dermatitis. J Pediatr 1989; 115: 23-7.

[26] Bock SA. The natural history of food sensitivity. J Allergy Clin Immunol 1982; 69: 173-7.
[27]

Boyano-Martínez MT, Martin Esteban M, Pascual C, Ojeda JA. Food allergy in children. II. Prognostic factors and long-term development. An Esp Pediatr 1987; 26: 241-5.

[28] Skripak JM, Matsui EC, Mudd K, Wood RA. The natural history of IgE-mediated cow's milk allergy. J Allergy Clin Immunol 2007; 120: $1172-7$

[29] Sampson HA, Ho DG. Relationship between food-specific IgE concentrations and the risk of positive food challenges in children and adolescents. J Allergy Clin Immunol 1997; 100: 444-51.

[30] Montesinos E, Martorell A, Félix R, Cerdá JC. Egg white specific IgE levels in serum as clinical reactivity predictors in the course of egg allergy follow-up. Pediatr Allergy Immunol 2010; 21: 634-9.

[31] Santos A, Dias A, Pinheiro JA. Predictive factors for the persistence of cow's milk allergy. Pediatr Allergy Immunol 2010; 21: $1127-34$

[32] Vanto T, Helppila S, Juntunen-Backman K, et al. Prediction of the development of tolerance to milk in children with cow's milk hypersensitivity. J Pediatr 2004; 144: 218-22.

[33] Levy Y, Segal N, Garty B, Danon YL. Lessons from the clinical course of IgE-mediated cow milk allergy in Israel. Pediatr Allergy Immunol 2007; 18: 589-93.

[34] Hill DJ, Hosking CS. Food allergy and atopic dermatitis in infancy: an epidemiologic study. Pediatr Allergy Immunol 2004; 15: 421-7.

[35] Tikkanen S, Kokkonen J, Juntti H, Niinimaki A. Status of children with cow's milk allergy in infancy by 10 years of age. Acta Paediatr 2000; 89: 1174-80.

[36] Lowe AJ, Abramson MJ, Hosking CS, et al. The temporal sequence of allergic sensitization and onset of infantile eczema. Clin Exp Allergy 2007; 37: 536-42.

(c) Giannetti et al.; Licensee Bentham Open.

This is an open access article licensed under the terms of the Creative Commons Attribution Non-Commercial License (http://creativecommons.org/licenses/bync/3.0/) which permits unrestricted, non-commercial use, distribution and reproduction in any medium, provided the work is properly cited. 